\title{
GREEN TECHNOLOGIES DEVELOPMENT IN THE EUROPEAN UNION AND LITHUANIA
}

\author{
Agnè Šneideriené $\dot{1}^{1}$ Henrika Rugine் ${ }^{2}$ \\ ${ }^{1}$ Klaipeda University. Minijos str. 153. 93185. Klaipeda. Lithuania. \\ Phone +370 46398 677. E-mail agne.sneideriene@ku.lt \\ ${ }^{2}$ Klaipeda University. Minijos str. 153. 93185. Klaipeda. Lithuania. \\ Phone +370 46398 677. E-mail henrika.rugine@ku.lt
}

Received 0506 2019; Accepted 30062019

The implementation and the development of green technologies is an essential way to ensure the transition from traditional economy model to the green growth. The purpose of the article assessing the importance of green technologies development in the European Union and Lithuania, to identify the trends associated with the development of green technologies. To achieve the purpose statistical data analysis had been conducted. Green technologies development can be seen in the European Union and Lithuania in 2008-2017 year period. But it should be noted that there are huge differences in adoption of these technologies among the countries of the European Union. These differences can be explained by the lack of financial resources and governmental support, differences in installed green technologies or involvement in such activities.

Keywords: green economy, green technologies, development, economic growth.

JEL Codes: D60, I31, O30, O52, Q20.

\section{Introduction}

Over the last decades, there has been recognized that traditional economic models should be replaced or reformed in order to address environmental issues (such as climate change, biodiversity losses, water scarcity) and key social and economic challenges. Technological innovations are a crucial component of a green economy transition (Droste et al., 2016), and there is an urgent need to develop and implement the green technologies into the existing facilities, especially in the developing countries (Li et al., 2015). The role of low carbon energy technologies for achieving green growth is underlined by the International Energy Agency (IEA, 2009).

Copyright (C) 2019 The Authors. Published by Vytautas Magnus University, Lithuanian Institute of Agrarian Economics. This is an open-access article distributed under the terms of the Creative Commons Attribution-NonCommercial 4.0 (CC BY-NC 4.0) license, which permits unrestricted use, distribution, and reproduction in any medium, provided the original author and source are credited. The material cannot be used for commercial purposes. 


\section{Agnè Šneiderienè, Henrika Ruginè. Green technologies development in the European union and Lithuania}

The use of green technologies could help to control environmental pollutions and enhance resource recovery; lead to better environment management system and achieving green economy (Styles et al., 2009, van Loon-Stennsma et al., 2014, Li et al., 2015). It should be noted that many local industries and enterprises lack access to green technology. This lack is explained by the fact that institutional, regulatory, and financial barriers have influence in creating or even extending technological barriers and disturbing the process of new technology creation. According to Li et al. (2015), if countries do not deal with these barriers, green technologies won't be created; so in the future, it would be even more difficult to undertake different environmental issues, such as climate change, loss of biodiversity, and others. According to Yang et al. (2019), remarkable positive effects on the efficiency of industrial green development also have such factors: technological progress, industrial scale, R\&D input intensity, and industrial output per unit energy consumption. Green technology development requires time, knowledge and financial capabilities, so businesses, regions and countries, especially developing ones, face economic challenges when environmental issues are integrated in the economic growth model. So, scientific problem can be formulated - to identify with what challenges faces the countries of the European Union while developing green technologies.

The purpose of the article assessing the importance of green technologies development in the European Union and Lithuania, to identify the trends associated with the development of green technologies.

The object of the research is the development of green technologies by country. The subject of research is the economic challenges associated with the development of green technologies in the European Union, as a whole, and Lithuania, as one of EU countries members.

Research methods: Statistical analysis for the period of 2008-2017 of such data have been conducted: the share of energy from renewable sources, the share of energy from renewable sources (RS) in transport, the share of energy from RS in electricity, the share of energy from RS in heating and cooling. According to this data, there was evaluated an increase rate of share of energy from RS in different sectors during the period of 20082017, and all countries members were ranked axccording estimated increase rate. Analysis of using different technologies for electricity production and the installed capacities during the period of 2008-2017 have been conducted. There have been also analyzed employment in the different bioenergy markets, overall turnover in the different bionergy markets and bioenergy dependency in the European Union.

Research results: conducted analysis has showed that in Lithuania electricity capacity technologies are installed 3 times faster and electricity generation growth 2.5 times faster than in the European Union. Despite this fact, it should be noted that there is a lack of marine technologies in Lithuania; wind technologies are usually introduced. 
The highest growth rates have been recorded in Malta and Cyprus; because these two countries have started install green technologies in 2010.

The research results, which reflect the state of the green technologies development have theoretical and practical value and can be used for further research or educational purpose, as well as for the development of recommendations to promote green technologies.

\section{Theoretical provisions of the importance of the green technologies}

Green economy and green development has become an important trend globally because it incorporate in economic growth such issues as global climate change, resource shortages, and environmental pollution. Gibbs and O'Neill (2017) assume that a concept of a green economy has led to a policy focus upon the potential for change to existing socio-economic development pathways. According to Lindman, Söderholm (2016), the green economy policy discourse recognizes the importance of actively promoting investments in new technologies that can open up the energy sector from the incumbent and typically less sustainable technologies based on fossil fuels and other energy resources that are non-renewable. According to Droste et al. (2016) any economic strategy will require investments, but the normative green economy vision needs both private and public investment to be steered towards greener and fairer strategies. It is therefore recognized that such investments have to be "supported by targeted public expenditure, policy reforms, and regulation changes" (UNEP, 2011, p. 16) which stresses the role of government intervention.

Yang et al. (2019) underline, that many countries have highlighted green development as an important measure for the promotion of regional sustainable development. The European Union has adopted technological and market-driven approaches to achieve green industries and low-carbon development. But it should be emphasized that in the European Union there is no singular green economy strategy, aspects of green economy are integrated in other sustainable development, energy, lowemission, and resource efficiency strategies (Pitkänen et al., 2016). In Lithuania's strategy "Lithuania 2030" have been separated three main priorities: smart society, smart economy and smart governance. It should be noted that there is emphasized that attention will be paid to create an economy that is flexible and able to compete globally, generating high added value and based on knowledge, innovations entrepreneurship and social responsibility as well as green growth. Schanesa et al. (2019) separate that growth and innovation in Europe are stimulated by these key factors: high level of technological advancement in the field of energy efficiency, more resource-efficient consumption and production patterns, innovation and large scale market mechanisms, technology transfer, the growth of global product agreements also supports the move towards resource efficiency. 
World Bank (2012) argues that green policies can contribute to growth through four effects: an input effect (increasing production factors), an efficiency effect (bringing production closer to the production frontier), a stimulus effect (stimulating the economy in times of crisis), and an innovation effect (accelerating development and adoption of technologies). Meanwhile, Wanner (2015) emphasize that in the green economy/growth discourse that there is no 'one size- fits-all' prescription for green growth strategies as there are different contexts of policy and institutional frameworks, economic and political circumstances, levels of development, and economic and environmental interdependencies, which also mean that "advanced, emerging, and developing countries will face different challenges and opportunities" (OECD, 2011, p. 10). As stated in UNEP (2011), in order to enable the economy transition towards a green economy, there is a need to mainstream environmental and social integration, ensure public and private financing, and sustainable trade process; products should fully cover all related costs. Also there is a need of development of innovation and technologies transfer process. It should be noted, that indicators for assessment of green economy should be also proposed. The relation between green economy and green technologies development is presented in Fig. 1.

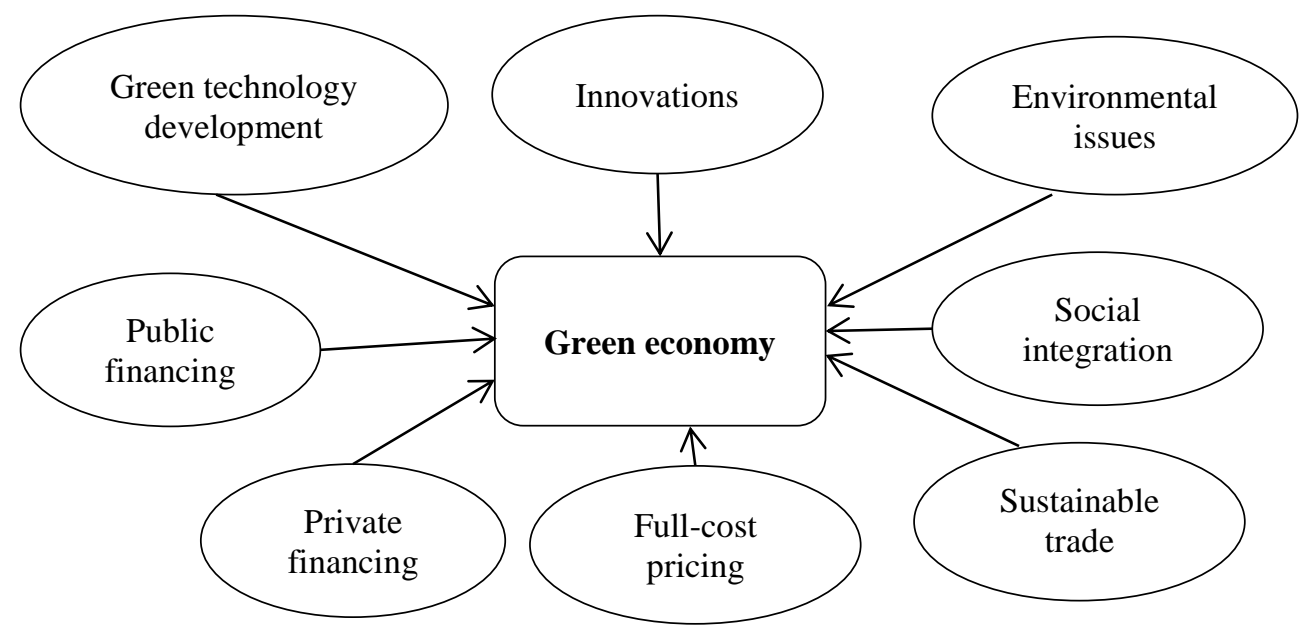

Fig.1. Green economy sub-sectors

Source: own elaboration according to UNEP (2011).

Technological innovations are a crucial component of a green economy transition (Droste et al., 2016); there is an urgent need of developing and implementing such kind of technologies in the existing facilities, especially, according to $\mathrm{Li}$ et al. (2015), in the developing countries because they face the lack of green technologies implementation. Yang et al. (2016), Chen et al. (2006) define green technologies as hardware or software innovation and relates them to green products or processes. These innovations also encompass innovations in energy saving, pollution prevention, waste recycling, green product designs, or corporate environmental management processes. 
The role of low carbon energy technologies for achieving green growth is underlined by the International Energy Agency (IEA, 2009). Dean, McMullen (2007), Demirel et al. (2019) emphasize the role of investments into environmentally sustainable technologies. These investments are crucial in order to address environmental issues and facilitate the shift toward low carbon economy. Constantini, Mazzanti (2012), Ghiseti, Quatraro (2013) highlight the role of investments in green technologies in restoring the competitiveness of economies, creating competitive advantages and providing new jobs, especially in advanced economies. Leoncini et al. (2019) investigate the relationships between green/non-green technologies and firm growth with particular focus on the corporate life cycle and find out that environmental technologies exert superior effects on the rate of growth compared to non-green technologies.

The use of green technologies could help to control environmental pollutions and enhance resource recovery; lead to better environment management system and achieving green economy (Styles et al., 2009, van Loon-Stennsma et al., 2014, Li et al., 2015). It should be noted that many local industries and enterprises lack access to green technology. This lack is explained by the fact that institutional, regulatory, and financial barriers have influence in creating or even extending technological barriers and disturbing the process of new technology creation. According to Li et al. (2015), if countries do not deal with these barriers, green technologies won't be created; so in the future, it would be even more difficult to undertake different environmental issues, such as climate change, loss of biodiversity, and others. According to Lindman, Söderholm (2016), introduction of new green technologies following $\mathrm{R} \& \mathrm{D}$ efforts will affect future innovations through different learning processes, for example, learning by doing, learning by using and vice versa. This process will lead to the re-development of a technology. It should be emphasized, that an important reason for the existence of such feedback effects is that experiences of the production and use of a technology often lead to the encountering of new problems and the discovery of new opportunities. According to Yang et al. (2019), remarkable positive effects on the efficiency of industrial green development also have such factors: technological progress, industrial scale, $R \& D$ input intensity, and industrial output per unit energy consumption. These authors also emphasize the role of economic development level on developing green economy. Studies of Miao et al. (2017), Zuo et al. (2017), Feng et al. (2018) show that technology innovations have impact on green development by reducing the environmental pollution and increasing the efficiency of natural resources. Five dimensions of economic development level, industrial structure, high and new technology, urban scale, and environment have a positive influence on green industrial development (Yang et al., 2019). According to Popp et al. (2007), public policy plays an important role in the adoption of environmental innovations and technologies. R\&D subsidies are necessary in order to promote implementation of environmentally beneficial technologies. 
This financial dependence of green innovation to public subsidies has been also confirmed by De Marchi (2012), Belin et al. (2011). Other drivers that have impact on development of technologies are organizational capabilities and customer demand for environmentally friendly products.

To sum up, technology innovation is the most critical driving factor of green development through enhancing the efficiency of natural resources or reducing the environmental pollution. But, many local industries and enterprises lack access to green technology. Institutional, regulatory, and financial barriers further exacerbate technological barriers by preventing the creation of new technology. If these barriers are not dealt with and green technology is not created, it will be even more difficult in the future to address different issues (climate change, loss of biodiversity, and other environmental problems) enhancing economic growth. The green economy meaning is consisting from many components and not everywhere in scientific literature or governmental strategies used this term. There are still needed lots of changes in all economies to become green orientated.

\section{Analysis of green technologies development in the European Union}

Part of green economy is usage of less polluting resources that are green technologies and also which are renewable. That is why so important European strategies in usage of renewable resources. In order to analyze green technologies development and identify main challenges related to this process, statistical data analysis was conducted. Indicators related to green technologies implementation and development was analyzed. The data statistics was taken from Eurostat, IRENA web sites because of the data availability for all EU countries. Such data for the period of 2008-2017 year were analyzed: the share of energy from renewable sources, the share of energy from renewable sources in transport, the share of energy from renewable sources in electricity, the share of energy from renewable sources in heating and cooling. According to this data, there was evaluated an increase rate of share of energy from renewable sources in different sectors during the period of 2008-2017, and all countries members were ranked axccording estimated increase rate. Also analysis of using different technologies for electricity production and the installed capacities during the period of 2008-2017 have been conducted. There have been also analyzed employment in the different bioenergy markets, overall turnover in the different bionergy markets in the European Union. It should be noted, that despite variety of green technologies, but main statistical data is accumulated just related to renewable resources and its technologies. So, in order to analyze green technologies development trends in EU and Lithuania, statistical data analysis on renewable resources was conducted. 
Studying statistical data on the renewable energy in Europe it can be seen (see Fig.2) that some countries are still far away from green economy concepts implementation. Although all EU members have agreed to achieve goals which are stated in Strategy 2020 on renewable energy sources. Sweden is the leader producing and using renewable energy sources $-54.5 \%$ of its energy was produced by using renewable sources in 2017. Moreover, the use of renewable energy sources in Sweden increased from 45.22 $\%$ in 2008 to $54.5 \%$ in 2017. Other countries leading in producing and using renewable sources in its gross final consumption of energy are Finland (41\%), Latvia (39\%), Denmark (35.77\%), and Austria (32.56\%) in 2017. Lithuania has exceeded the plan of $23 \%$ named in the strategy and in 2017 has already reached $25.8 \%$ of energy from renewable sources. The lowest proportions of renewable sources used for producing the energy are in Malta (7.17\%) and Netherlands (6.6\%). But it should be noticed that in Malta production of renewable energy sources has increased significantly from $0.2 \%$ in 2008 to $7.17 \%$ in 2017, the total increase during this period was $3485 \%$. Each EU Member State has stated own targets of renewable energy sources related to Europe 2020 strategy. As it can be seen from Fig. 2, only 11 countries (Sweden, Finland, Romania, Lithuania, Italy, Hungary, Croatia, Estonia, Denmark, Czech Republic, Bulgaria) of 28 EU Member States in 2017 have already reached their planned share of energy production and use from renewable sources as stated in EU 2020 Strategy.

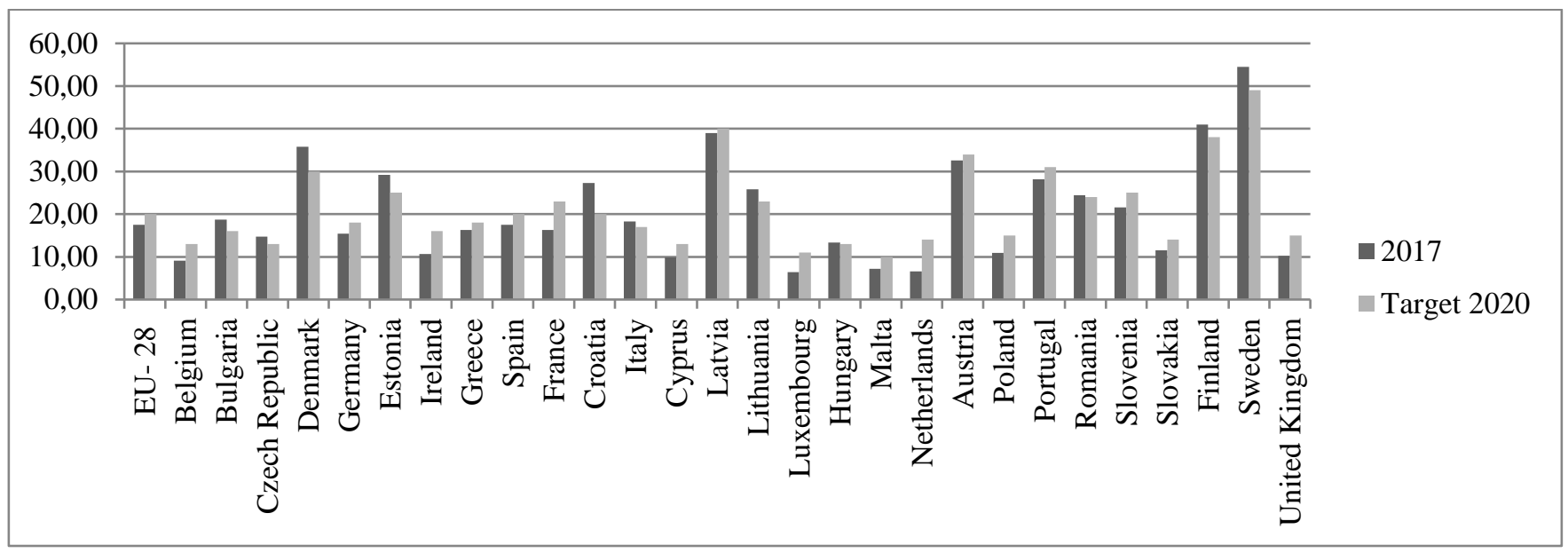

Fig.2. Share of energy from renewable sources (in \% of gross final energy consumption) Source: Eurostat (2019a; 2019b).

The share of renewable energy consumption in the EU as whole reached $17.5 \%$ in 2017, an increase of $0.5 \%$ comparing with previous year or $55 \%$ increase comparing with 2008. Such an increase in renewable energy source production gives a hope that 2020 goal will be reached in nearly all states. EU average consumption of renewable energy is stated $20 \%$ in the strategy 2020 . There are some states that are very close to their target and definitely will reach it by 2020 . 
On the other hand, some countries are still far away from their stated goals. That would be Ireland with $-5.35 \%$, France with $-5.7 \%$ and Netherlands with $-7.4 \%$ from stated goals in the Europe 2020. Although Lithuania already reached the target, but the planned percentage was not really impressing and are still needed lots of alterations in economic system to reached higher results.

In table 1 there are provided data from conducted analysis of the changes in using and producing energy in transport, electricity, heating and cooling during the period of 2008-2017 in the European Union. In order to evaluate increase rates, countries are ranked according conducted analysis.

Table 1. The changes of shares of renewable sources (RS) in energy, transport, electricity and heating and cooling in the European Union, 2008-2017

\begin{tabular}{|l|c|c|c|c|c|c|c|c|}
\hline \multirow{2}{*}{ Countries } & \multicolumn{2}{|c|}{$\begin{array}{c}\text { Renable energy } \\
\text { sources }\end{array}$} & \multicolumn{2}{c|}{ RS in transport } & \multicolumn{2}{c|}{ RS in electricity } & \multicolumn{2}{c|}{$\begin{array}{c}\text { RS in heating and } \\
\text { cooling }\end{array}$} \\
\cline { 2 - 11 } & $\begin{array}{c}\text { Increase } \\
\text { rate, \% }\end{array}$ & Rank & $\begin{array}{c}\text { Increase } \\
\text { rate, \% }\end{array}$ & Rank & $\begin{array}{c}\text { Increase } \\
\text { rate, \% }\end{array}$ & Rank & $\begin{array}{c}\text { Increase } \\
\text { rate, \% }\end{array}$ & Rank \\
\hline $\begin{array}{l}\text { European Union } \\
\text { - 28 }\end{array}$ & 54,77 & 16 & 94,34 & 16 & 81,20 & 17 & 41,47 & 19 \\
\hline Belgium & 152,37 & $\mathbf{4}$ & 961,29 & $\mathbf{2}$ & 274,78 & $\mathbf{5}$ & 59,96 & 14 \\
\hline Bulgaria & 78,55 & 10 & 732,18 & $\mathbf{3}$ & 91,97 & 15 & 72,83 & 8 \\
\hline Czechia & 71,03 & 11 & 147,37 & 12 & 163,51 & 9 & 52,09 & 15 \\
\hline Denmark & 92,73 & 7 & 1168,52 & $\mathbf{1}$ & 132,69 & 11 & 65,84 & 10 \\
\hline Germany & 53,88 & 17 & 9,33 & 26 & 129,55 & 12 & 30,29 & 22 \\
\hline Estonia & 56,79 & 14 & 135,29 & 13 & 805,85 & $\mathbf{3}$ & 45,63 & 17 \\
\hline Ireland & 167,59 & $\mathbf{3}$ & 467,18 & $\mathbf{5}$ & 178,61 & 8 & 95,44 & $\mathbf{3}$ \\
\hline Greece & 104,26 & 6 & 71,43 & 18 & 153,58 & 10 & 86,85 & $\mathbf{5}$ \\
\hline Spain & 63,04 & 12 & 174,07 & 10 & 53,01 & 19 & 50,90 & 16 \\
\hline France & 45,67 & 19 & 48,14 & 22 & 38,65 & 23 & 60,77 & 13 \\
\hline Croatia & 24,11 & 25 & 8,26 & 27 & 37,13 & 24 & 27,57 & 24 \\
\hline Italy & 59,01 & 13 & 151,16 & 11 & 104,80 & 14 & 31,16 & 21 \\
\hline Cyprus & 92,01 & 8 & 33,85 & 23 & 3078,57 & $\mathbf{2}$ & 69,25 & 9 \\
\hline Latvia & 30,86 & 23 & 50,30 & 21 & 40,36 & 22 & 27,11 & 25 \\
\hline Lithuania & 45,01 & 20 & $-13,99$ & 29 & 271,69 & 6 & 45,36 & 18 \\
\hline Luxembourg & 126,24 & $\mathbf{5}$ & 198,15 & 9 & 124,86 & 13 & 76,69 & 6 \\
\hline Hungary & 55,72 & 15 & 33,53 & 24 & 40,79 & 21 & 64,08 & 11 \\
\hline Malta & 3485,00 & $\mathbf{1}$ & 236,63 & 7 & 21833,33 & $\mathbf{1}$ & 1066,47 & $\mathbf{1}$ \\
\hline Netherlands & 82,83 & 9 & 101,02 & 15 & 84,74 & 16 & 93,79 & $\mathbf{4}$ \\
\hline Austria & 17,84 & 29 & 2,31 & 28 & 10,96 & 28 & 27,59 & 23 \\
\hline Poland & 43,42 & 22 & 21,04 & 25 & 199,54 & 7 & 33,46 & 20 \\
\hline
\end{tabular}


Management Theory and Studies for Rural Business and Infrastructure Development eISSN 2345-0355. 2019. Vol. 41. No. 2: 249-263

Article DOI: https://doi.org/10.15544/mts.2019.21

\begin{tabular}{|l|c|c|c|c|c|c|c|c|}
\hline & 22,58 & 26 & 215,94 & 8 & 59,04 & 18 & $-8,32$ & 29 \\
\hline Portugal & 19,19 & 28 & 89,05 & 17 & 48,25 & 20 & 14,72 & 27 \\
\hline Slovenia & 43,76 & 21 & 54,80 & 20 & 8,24 & 29 & 72,91 & 7 \\
\hline Slovakia & 48,45 & 18 & 61,61 & 19 & 25,46 & 26 & 61,31 & 12 \\
\hline Finland & 30,81 & 24 & 538,31 & $\mathbf{4}$ & 29,15 & 25 & 26,76 & 26 \\
\hline Sweden & 20,52 & 27 & 367,68 & 6 & 23,00 & 27 & 13,27 & 28 \\
\hline United Kingdom & 285,28 & $\mathbf{2}$ & 119,57 & 14 & 413,89 & $\mathbf{4}$ & 284,02 & $\mathbf{2}$ \\
\hline
\end{tabular}

As it can be seen from Table1, during the analysed period shares of energy renewable sources in energy, in electricity and in heating and cooling have increased significantly in Malta. It should be noted that in Lithuania a share of renewable sources in transport have decreased during this period. Although Sweden is a leader in energy production from renewable sources, but during 2007-2018 period, the increase in share was not so significant; only by increase in shares of energy renewable sources in transport, Sweden can be ranked as 6 comparing with other European Union countries and the European Union as a whole. It should be noted, that despite an increase of renewable resources consumer in transport and heating and cooling sectors, these sectors are still lagging compared with electricity sector. In 2016 only Austria (10.6\%) and Sweden (30.3\%) had reached the target to use $10 \%$ of bioful in transport until 2020. In Lithuania, this measure have reached only $3.6 \%$.

In order to compare the use of electricity generation sources from different types of technologies, in Fig. 3 and Fig. 4 there are compared the cases of Lithuania and the European Union.

In Lithuania (see Fig. 3) electricity most often is produced using wind technologies (54\%), and renewable hydropower, but there is a lack of marine technologies. In the European Union the amount of used renewable hydropower and wind technologies are almost the same: respectively $-37 \%$ and $32 \%$. Analyzing the changes in producing electricity using various types of renewable sources during 2008-2017 period in countries of the European Union, it can be said that there are huge differences. Austria has stopped using geothermal technologies during this period. A decrease in using hydropower has been seen in these countries: Denmark (-27\%), Ireland (-25\%), Latvia (-18.6\%), Belgium $(-15 \%)$, Sweden $(-10 \%)$, Finland $(-7.8 \%)$, Italy $(-6.3 \%)$, France $(-5 \%)$. Generated electricity using renewable energy technologies increased almost $69 \%$ in the European Union. This measure have most increased in Malta (44366\%), Cyprus (2726\%), because these countries have just started producing energy by using renewable technologies in 2009 or 2010 years. The increase also has been noticeable in Estonia (673\%), UK (281\%), Lithuania (246\%), Poland (245\%), Greece (159\%), this increase is above the average increase of the European Union. Slight increase is seen in Slovenia (17\%) and Sweden $(9 \%)$. 


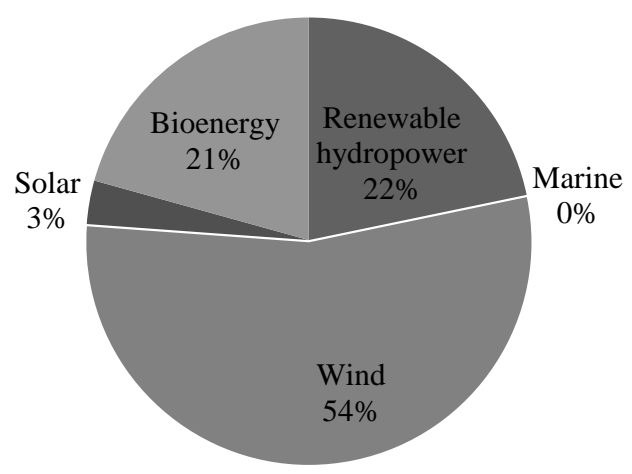

Fig.3. Electricity generation of installed renewable energy technologies in Lithuania in 2016 Source: IRENA (2018).

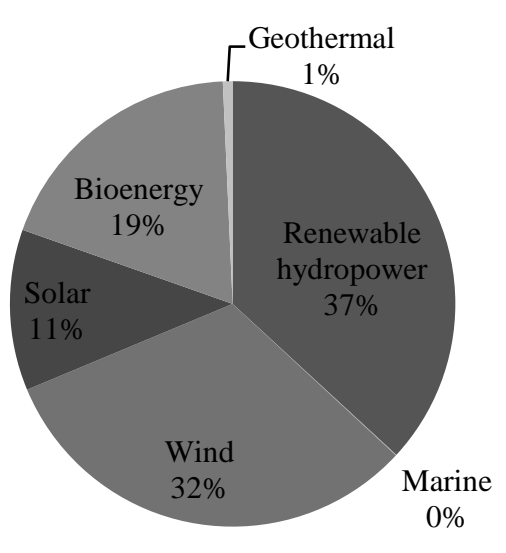

Fig.4. Electricity generation of installed renewable energy technologies in the European Union in 2016 Source: IRENA (2018).

It should be noted, that it is anticipated increase in bioenergy use for heat in the European Union by around $8 \%$ by 2023 . Mostly biomass heat is used in buildings. The voluntary target within the updated Renewable Energy Directive (RED), for member states to increase renewable energy in heating and cooling by 1.3 percentage points/year should open up opportunities for biomass heating.

In order to compare what types of technologies have been used most often, in Fig. 5 and Fig. 6 there are presented the cases of Lithuania and the European Union.

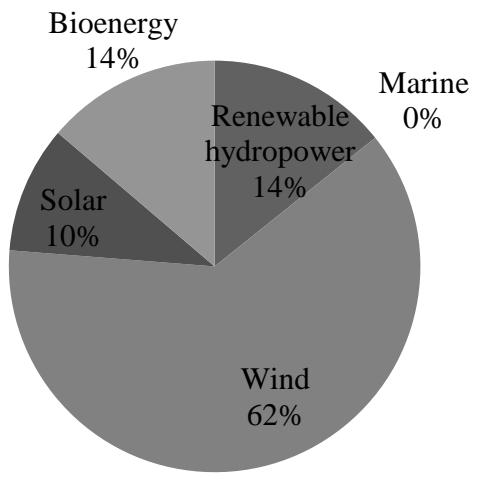

Fig.5. Installed renewable energy technologies capacities in Lithuania in 2017

Source: IRENA (2018).

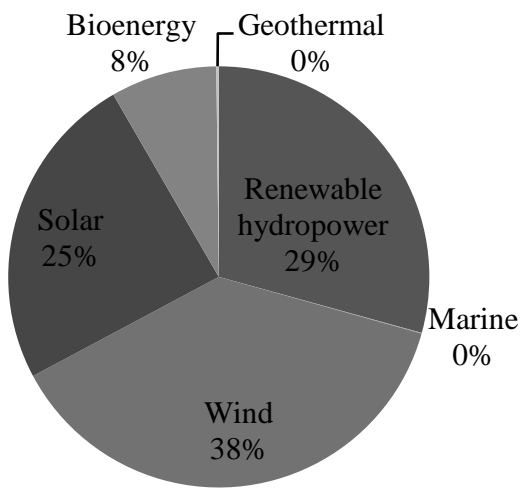

Fig.6. Installed renewable energy technologies capacities in the European Union in 2017

Source: IRENA (2018). 
As it can be noticed from Fig. 5, Lithuania has usually been installed wind technologies capacities, bioenergy and renewable hydropower technologies capacities have increased in the same speed. And still there is a lack of installed capacities in order to use marine technologies. Analyzing installed capacity in 2017 in the European Union, it can be said that the highest renewable energy is wind $-38 \%$ of installed capacities. Installed renewable energy technologies capacities have increased in the European Union almost twice - 105\% - during the period of 2008-2017. Meanwhile, such technologies capacities have increased almost 325\% in Lithuania. The most significant increase has been noticeable in Malta (57450\%) and Cyprus (2932\%), because of the lack of these technologies before 2009 .

The energy dependency of the European Union countries is also much closed related to green technologies development. The energy dependency is defined as net energy imports divided by gross inland consumption. According to the data, net exporting countries can be identified: Latvia (-58.7\%), Estonia (-54.3\%), Netherlands (-34.7\%), Croatia $(-21.8 \%)$. Lithuania can also be assigned as net exporting country, but the rate is insignificant and seeks only $-2.9 \%$ of total biomass. The import dependency of the European Union states is only $4.1 \%$ for bioenergy, which compares favorably to the import dependency for fossil fuels, which is close to $90 \%$. Bioenergy remains a local source of energy in the European Union. It is also notable that bioenergy has decreased it imports' dependency since 2015 , from $4.4 \%$ to $4.1 \%$. It is clear from these figures that trade of biomass takes place primarily between EU Member States. This underlines the necessity of harmonized sustainability criteria and quality standards to ensure a fair bioenergy market within EU Member States.

An important measure analyzing economic issues related with green technologies development is direct and indirect employment in the different renewable energy sectors. It should be noted that bioenergy is the largest renewable energy source in terms of direct and indirect employment, accounting for 659.600 jobs in the solid biomass, biofuels, biogas, and renewable municipal waste sectors in the European Union. Relying on feedstocks from agriculture and forests, biomass is relatively job-intensive in comparison to other types of energy. For instance, it generates ten times more jobs than nuclear energy for each unit of energy produced. Also, bioenergy is largely produced in rural areas and thus has a positive impact on the income of farmers and forest owners. Only $2.27 \%$ of the European Union employees employed in renewable energy sectors are working in Lithuania. The biggest part of them have been employed in liquid biofuels sector (9 200 employees or $61.33 \%$ of all employed workers). The biggest parts of employees employed in different bioenergy sectors in the European Union are in Denmark (16.2\%), France (11.3\%), Poland (9.7\%), Romania, and Spain - 5.4\% and Finland (4.45\%). These six countries accounts for $52.45 \%$ of all European Union employment in sectors related to renewable resources. 


\section{Agnè Šneiderienè, Henrika Ruginè. Green technologies development in the European union and Lithuania}

Another important measure related to green technologies development is overall turnover. In 2015, the overall turnover of bioenergy represented 56 billion $€$ in the European Union. Solid bioenergy experienced strong growth in recent years with an increase in turnover from 25 billion $€$ in 2010 to around 32 billion $€$ in 2016 in the European Union. With this amount, the European Union is the global leader in bioenergy. In Lithuania overall turnover of bioenergy represented just 570 million $€$ or almost $1 \%$ of total European Union turnover. It should be noted that almost $51 \%$ of these turnovers have been generated in biofuels sector and $45.6 \%$ in solid biomass sector. Renewable municipal waste and biogas have generated only $3.5 \%$ and $1.7 \%$ of all Lithuania's turnovers of bioenergy. The largest parts of overall turnover of bioenergy of the European Union have been generated in Denmark (22.4\%), France (14.3\%), Sweden (8.2\%), and Italy (8.1\%). These four countries accounts for 53\% of overall turnover of bioenergy in the European Union.

In November of 2018, European Commission (COM, 2018) adopted a strategic long-term vision for a prosperous, modern, competitive and climate neutral economy by 2050 - A Clean Planet for all. The strategy will require scaling up of technological innovations in energy, buildings, transport, industry, and agriculture. It shows how Europe can lead the way to climate neutrality by investing into realistic technological solutions, empowering citizens, and aligning action in key areas such as industrial policy, finance, or research - while ensuring social fairness for a just transition.

The long-term strategy looks into the portfolio of options available for Member States, business and citizens, and how these can contribute to the modernization of economy and improve the quality of life of the European Union members. The strategy seeks to ensure socially fair transition and enhances the competitiveness of EU economy and industry on global markets, securing high quality jobs and sustainable growth in Europe, while also helping address other environmental challenges, such as air quality or biodiversity loss. The document describes climate neutral economy and required joint action in seven strategic areas: energy efficiency; deployment of renewable; clean, safe and connected mobility; competitive industry and circular economy; infrastructure and interconnections; bio-economy and natural carbon sinks; carbon capture and storage to address remaining emissions.

To summarize, it can be seen green technologies development in the European Union and Lithuania in 2008-2017 year period. But it should be noted that there are huge differences in adoption of these technologies among the countries of the European Union. These differences can be explained by the lack of financial resources. Not all types of green technologies are installed in all European Union countries. Moreover, some countries are far away from others of developing green technologies, while, others still are facing difficulties. Lithuanian situation shows that there are not enough of attention and ambitions to expand growth of renewable resources and other green technologies in the country. Although there are some projects and initiatives, but there is lack of 
governmental support and ambitious planning. There should be placed more attention to green economy development in Lithuania from the business side, but it is possible only with more governmental support and attention.

\section{Conclusions}

Huge differences exist in development of green technologies in the European Union and Lithuania. Only 11 European Union countries members had reached targeted goals on the share of energy production and use from renewable sources. It should be noted that bioenergy remains a local source of energy in the European Union. Different kinds of green technologies have been installed in the European Union, and it is seen a decrease in using hydropower technologies. Six countries (Denmark, France, Poland, Romania, Spain, and Finland) accounts for 52.45\% of all European Union employment in sectors related to renewable resources, but only four countries (Denmark, France, Sweden and Italy) accounts for 53\% of overall turnover of bioenergy in the European Union.

Although Lithuania had reached targeted goals on the share of energy production and use from renewable sources, but it is behind other European Union countries in adoption green technologies. It should be stated, that in Lithuania there is still a lack of marine technologies. Though, Lithuania is not bioenergy dependent, but this rate is insignificant. Employment in the different renewable energy sectors accounts only for almost $2.27 \%$ of total EU employment and overall turnover of bioenergy accounts only for $1 \%$ of total European Union turnover. The more ambitious governmental planning and support in Lithuania would help to expand more green economy prevalence.

Main challenges on green technologies development are related with insufficient use of renewable resources in transport and heating and cooling sectors, huge differences in installing renewable energy capabilities, lack of financial resources, and lack of governmental support.

\section{References}

Belin, J., Horbach, J., Oltra, V. (2011). Determinants and specificities of eco-innovations: an econometric analysis for the French and German industry based on the community innovation survey. https://www.researchgate.net/publication/228933923 [15 03 2019].

Chen, Y., Lai, S., Wen, C. (2006). The influence of green innovation performance on corporate advantage in Taiwan // Journal of Business Ethics. No 67(4): 331-339.

COM (2018). A Clean Planet for all. - https://eur-lex.europa.eu/legalcontent/EN/TXT/?uri=CELEX:52018DC0773 [20 03 2019].

Constantini, V., Mazzanti, M. (2012). On the green and innovative side of trade competitiveness? The impact of environmental policies and innovation on EU exports // Research Policy. No. 41(1): 132153.

Dean, T. J., McMullen, J. S. (2007). Towards theory of sustainable entrepreneurship: reducing environmental degradation through entrepreneurial action // Journal of Business Venturing. No. 22(1): $50-76$. 


\section{Agnè Šneiderienè, Henrika Ruginè. Green technologies development in the European union and Lithuania}

De Marchi, V. (2012). Environmental innovation and R\&D cooperation: empirical evidence from Spanish manufacturing firms // Research Policy. No. 41(3): 614-623.

Demirel, P., Li, C. Q., Rentocchini, F., Tamvada, J. P. (2019). Born to be green: new insights into the economics and management of green entrepreneurship // Small Business Economics. No. 52(4): 759771.

Droste, N., Hansjürgens, B., Kuikman, P., Otter, N., Antikainen, R., Leskinen, P., Pitkänen, K., Saikku, L., Loiseau, E., Thomsen, M. (2016). Steering innovations towards a green economy: understanding government intervention // Journal of Cleaner Production. No. 135: 426-434.

Eurostat (2019a). Share of energy from renewable resources. http://appsso.eurostat.ec.europa.eu/nui/show.do?dataset=nrg_ind_ren\&lang=en [20 03 2019].

Eurostat (2019b). Share of renewables in energy consumption in the EU reached $17 \%$ in 2016. https://ec.europa.eu/eurostat/documents/2995521/8612324/8-25012018-AP-EN.pdf/9d28caef-19614dd1-a901-af18f121fb2d [20 03 2019].

Feng, C., Huang, J. B., Wang, M. (2018). Analysis of green total-factor productivity in China's regional metal industry: a meta-frontier approach // Resource Policy. No. 58: 219-229.

Gibbs, D., O`Neill, K. (2017). Future green economies and regional development: a research agenda // Regional Studies. No. 51(1): 161-173.

Ghisetti, C., Quatraro, F. (2013). Beyond inducement in climate change: does environmental performance spur environmental technologies? A regional analysis of cross-sectoral differences // Ecological Economics. No. 96: 99-113.

IEA (2009). Ensuring green growth in a time of economic crisis: the role of energy technology. https://www.iea.org/publications/freepublications/publication/ensuring_green_growth.pdf [15 03 2019].

IRENA (2018). Renewable Energy Statistics. - https://www.irena.org/ourwork/Knowledge-DataStatistics/Data-Statistics/Capacity-and-Generation/Regional-Trends [20 03 2019].

Yang, L. R., Chen, J. H., Li, H. H. (2016). Validating a model for assessing the association among green innovation, project success and firm benefit // Quality \& Quantity: International Journal of Methodology. No. 50(2): 885-899.

Yang, Y., Guo, H., Chen, L., Liu, X., Gu, M., Ke, X. (2019). Regional analysis of the green development level differences in Chinese mineral resource-based cities // Resource Policy. No. 61: 261272 .

Leoncini, R., Marzucchi, A., Montresor, S., Rentocchini, F., Rizzo, U. (2019). 'Better late than never': the interplay between green technology and age for firm growth // Small Business Economics. No. 52(4): 891-904.

Li, J., Pan, S. Y., Kim, H., Linn, J. H., Chiang, P. C. (2015). Building green supply chains in ecoindustrial parks towards a green economy: barriers and strategies // Journal of Environmental Management. No. 162: 158-170.

Lindman, A., Söderholm, P. (2016). Wind energy and green economy in Europe: measuring policy-induced innovation using paten data // Applied Energy. No. 179: 1351-1359.

Lithuania's progress strategy "Lithuania 2030". - https://www.docdroid.net/ERhjMs3/enlietuva2030.pdf\#page $=8$ [15 03 2019].

Miao, C., Fang, D., Sun, L., Luo, Q. (2017). Natural resources utilization efficiency under the influence of green technological innovation // Resources, Conservation and Recycling. No. 126: 153161.

OECD (2011). Towards green growth: monitoring progress OECD indicator. https://www.oecd.org/greengrowth/48224574.pdf [15 03 2019] 


\title{
Management Theory and Studies for Rural Business and Infrastructure Development eISSN 2345-0355. 2019. Vol. 41. No. 2: 249-263
}

Article DOI: https://doi.org/10.15544/mts.2019.21

Pitkänen, K., Antikainen, R., Droste, N., Loiseau, E., Saikku, L., Aissani, L., Hansjürgens, B., Kuikman, P. J., Leskinen, P., Thomsen, M. (2016). What can be learned from practical cases of green economy? - studies from five European countries // Journal of Cleaner Production. No. 139: 666-676.

Popp, D., Hafner, T., Johnstone, N. (2007). Policy vs. consumer pressure: innovation and diffusion of alternative bleaching technologies in the pulp industry // NBER Working Paper No. 13439. - https://www.nber.org/papers/w13439.pdf [15 03 2019]

Schanesa, L., Jagerb, J., Drummond, P. (2019). Three scenario narratives for a resource-efficient and low-carbon Europe in 2050 // Ecological Economics. No. 155: 70-79.

UNEP (2011). Towards a green economy: pathways to sustainable development and poverty eradication. - https://sustainabledevelopment.un.org/content/documents/126GER_synthesis_en.pdf [15 03 2019].

van Loon-Steensma, J. M., Schelfhout, H. A., Vellinga, P. (2014). Green adaptation by innovative dike concepts along the Dutch Wadden Sea coast // Environmental Science and Policy. No. 44: 108-125.

Zuo, Y. Shi, Y. I., Zhang, Y. Z. (2017). Research on the sustainable development of an economicenergy-environment (3E) system based on system dynamics (SD): a case study of the Beiijing-TianjinHebei Region In China // Sustainability. No. 9(10): 1727-1750.

Wanner, T. (2015). The new "Passive Revolution" of the green economy and growth discourse: maintaining the "Sustainable Development" of Neoliberal capitalism // New Political Economy. No. 20(1): 21-41.

World Bank (2012). Inclusive green growth: the pathway to sustainable development. http://siteresources.worldbank.org/EXTSDNET/Resources/Inclusive_Green_Growth_May_2012.pdf [15 03 2019].

\section{ŽALIŲJŲ TECHNOLOGIJŲ PLĖTRA EUROPOS SĄJUNGOJE IR LIETUVOJE}

\author{
Agnẻ Šneiderienë* Henrika Ruginė \\ ${ }^{1,2}$ Klaipeda University. Minijos g. 153. 93185. Klaipeda. Lietuva \\ Pateikta 201906 05; priimta 20190630
}

Technologijų diegimas yra sudètinè ir esminè perèjimo prie žaliosios ekonomikos dalis. Būtina pabrėžti žaliųu technologijų plètojimo svarbą, ypač besivystančiose šalyse. Straipsnio, nagrinėjančio žaliujų technologijų plètrą Europos Sajungoje ir Lietuvoje, tikslas - nustatyti su kokiais iššūkiais susiduria šalys diegdamos ir plètodamos žaliąsias technologijas. Siekiant išsikelto straipsnio tikslo, atlikta žaliųjų technologijų plètros Europos Sajungoje ir Lietuvoje 2008-2017 metų laikotarpiu statistinių duomenų analizè. Nustatyta, kad egzistuoja dideli šių technologijų diegimo skirtumai Europos Sajungos valstybėse. Skirtumų astiradimui įtakos turèjo šie aspektai: finansinių išteklių ir vyriausybės paramos trūkumas, skirtingi žaliụjų technologijų diegimo tempai, valstybèse diegiamos skirtingos žaliosios technologijos.

Raktiniai žodžiai: žalioji ekonomika, žaliosios technologijos, plètra, ekonomikos augimas.

JEL kodai: D60, I31, O30, O52, Q20.

\footnotetext{
${ }^{*}$ Autorius pasiteirauti
} 